\title{
Induction of Brain Injury and Depression in Rats by Chronic Unpredictable Stress Associated with the Augmentation of Nitrosative Stress and Apoptosis
}

\author{
Inducción de Lesión Cerebral y Depresión en Ratas por Estrés Crónico \\ Impredecible Asociado con el Aumento del Estrés Nitrosativo y la Apoptosis
}

Ismaeel Bin-Jaliah

BIN-JALIAH, I. Induction of brain injury and depression in rats by chronic unpredictable stress associated with the augmentation of nitrosative stress and apoptosis. Int. J. Morphol., 38(5):1217-1222, 2020.

SUMMARY: Repeated stress is a risk factor for memory impairment and neurological abnormalities in both humans and animals. We sought to investigate the extent of (i) brain tissue injury; (ii) nitrosative and oxidative stress in brain tissue homogenates; (iii) apoptotic and survival biomarkers in brain tissue homogenates; and (iv) immobility and climbing abilities, induced over a period of three weeks by chronic unpredictable stress (CUS). Wistar rats were either left untreated (Control group) or exposed to a variety of unpredictable stressors daily before being sacrificed after 3 weeks (model group). Assessment of depression-like behavior was performed and animals were then culled and harvested brain tissues were stained with basic histological staining and examined under light microscopy. In addition, brain tissue homogenates were prepared and assayed for these parameters; inducible nitric oxide synthase (iNOS), malondialdehyde (MDA), superoxide dismutase (SOD), caspase-3, and B-cell lymphoma 2 (Bcl-2). Histology images showed CUS induced profound damage to the cerebral cortex as demonstrated by severe neuronal damage with shrunken cells, disrupted atrophic nuclei, perineuronal vacuolation and swollen glial cells. CUS also significantly $(\mathrm{p}<0.05)$ induced iNOS, MDA, and caspase-3, whereas SOD and Bcl-2 brain tissue levels were inhibited by CUS. In addition, data from the depression-like behavior, forced swimming test showed significant $(\mathrm{p}<0.05)$ increase in animal immobility and decrease in climbing ability in the model group of rats. Thus, here we demonstrated a reliable rat model of chronic stress-induced brain injury, which can further be used to investigate beneficial drugs or agents used for a period of three weeks to protect against CUS-induced brain damage.

KEY WORDS: Brain injury; Chronic stress; Apoptosis and survival; Nitrosative and oxidative stress; Rat model.

\section{INTRODUCTION}

A continuous exposure to stressors for a prolonged period of time in humans and animals can lead to chronic stress that could affect vital organs such as the brain and heart (Helmreich et al., 2005; O'Donnell et al., 2008). Indeed, chronic stress can act as a trigger for stress-related mental disorders such as depression and general anxiety disorder (Bondi et al., 2008). Also, chronic stress caused cardiac arrest and death in more than a quarter of the mice that had serotonin receptor knockout (Carnevali et al., 2012). Mental stress, depression and anxiety are recognised among many risk factors that trigger myocardial infarction (Dimsdale, 2008).

To cope with stress, the body mobilizes physiological and psychological resources leading to alterations in the dynamic regulations of the autonomic, neuroendocrine, and immune systems (Pike et al., 1997). Accumulated evidence shows that chronic stress such as those arising from natural disasters, wars, economic deprivation or induced by experimental procedures, is a risk factor for the central and peripheral nervous systems (Alkadhi et al., 2013; Hovatta et al., 2010). For example, (i) exposure to various forms of psychological or occupational stressors resulted in stimulation of the hypothalamic-pituitary adrenal axis which leads to the increase in secretion of the stress hormone cortisol (Alkadhi et al.); and (ii) oxidative damage to neurons has been implicated in the pathogenesis of depression (Nunomura et al., 2014).

Tissue oxidative stress is believed to be the main cause behind damage which occurs in animals and humans 
exposed to traumatic events including chronic stress (Chew \& Toyokuni, 2015). Stress-induced overproduction of reactive oxygen species (ROS) caused apoptosis and enhanced levels of lipid peroxidation and peroxynitrite that damages DNA in the brain (Won et al., 1999). In addition, the brain's oxygen demand is particularly high and the presence of antioxidant defense mechanisms is relatively limited (Ng et al., 2008). Indeed, the role of lowered levels of antioxidants and high generation of ROS and nitrosative stress in the pathogenesis of depression have been reported, which have pointed to neuroinflammation, increased apoptosis rate and altered neurogenesis/neuroplasticity (Maes et al., 2011). Therefore, we speculated that CUS induction in rats for a period of 21 days can cause brain tissue damage associated with the augmentation of tissue nitrosative and oxidative stress and apoptosis in a rat model of the disease.

\section{MATERIAL AND METHOD}

Animals. Experiments were performed with the approval of the Research Ethics Committee at the College of Medicine, King Khalid University, Abha, Saudi Arabia, and all procedures were performed according to the Guide for the Care and Use of Laboratory Animals published by the US National Institutes of Health (NIH publication No. 85-23, revised 1996). Male Wistar rats of 8 weeks and weighing $230 \pm 10 \mathrm{~g}$, were used for the experiments and kept at the animal house of the College of Medicine, where they were fed standard rat pellets and allowed free access to water. The housing conditions were a controlled ambient temperature of $25 \pm 2{ }^{\circ} \mathrm{C}$ and $50 \pm 10 \%$ relative humidity, with 12-h light/12-h dark cycles.

Experimental design. After a one-week adaptation period, rats were randomly assigned to 2 groups $(\mathrm{n}=6$ each) as follows: 1. Control group, the untreated group of rats. 2 . Chronic unpredictable stress (CUS), the model group: Rats exposed to CUS protocol, as detailed below.

Chronic unpredictable stress (CUS) protocol. CUS protocol was induced as previously described (Harro et al., 1999) with modification. Briefly, a set of chronic unpredictable stressors were used to induce brain injury in rats that lasted for 3 weeks.

Assessment of depressive-like behavior forced swimming test. The experiment was carried out as previously described (Yankelevitch-Yahav et al., 2015) with a minor modification. Briefly, on the first day (pre-test session), rats were placed individually in a clear cylinder (20-cm diameter, $50-\mathrm{cm}$ height) that contained water $(25 \pm$ $1^{\circ} \mathrm{C}$ ) to a depth of $25 \mathrm{~cm}$ and forced to swim for $15 \mathrm{mins}$. Subsequently, rats were removed from the cylinder, dried with towels, and warmed by a heater before being returned to their home cages. The water in the tank was replaced after it was used by each animal. On the following day (test session), rats were placed back into the cylinder for 5 $\mathrm{min}$. A 5-s sampling procedure was utilized for scoring the behavior (i.e., immobility and climbing). Immobility was noted if the rat remained floating in the water without struggling and only made movements to keep its head or nose above the water. "Climbing" was defined as the animal making upwardly directed vigorous movements of the forepaws usually along the cylinder wall while keeping its head and shoulders above the water. All scoring was done by a single trained person, blind to experimental conditions.

Preparation of brain tissues for analysis. Four hours after the last stressor, rats were anaesthetized with a $1 \%$ solution of sodium pentobarbital $(50 \mathrm{mg} / \mathrm{kg}$; i.p.) and then sacrificed by cervical dislocation. Brain tissues were collected and washed with iced phosphate buffered saline (PBS). The brains were cut in longitudinal sections. Parts of the brains were homogenized with an ultrasonic homogenizer in cold phosphate buffer, $\mathrm{pH}$ 7.4, containing EDTA. The supernatant obtained was distributed in separate tubes and stored at $-70{ }^{\circ} \mathrm{C}$ for biochemical analysis. Other parts of the brains were stored at $-70^{\circ} \mathrm{C}$ for RNA extraction.

Histological study. Brain specimens were dissected and immediately fixed in $10 \%$ formol saline for 24 hours. Paraffin blocks were processed, sectioned in $5 \mu \mathrm{m}$ thickness and subjected to H\&E staining to observe the morphological changes.

Determination of tissue levels of nitrosative and oxidative stress, and apoptosis and survival biomarkers. Prepared brain tissue homogenates were used to determine tissue levels of malondialdehyde (MDA) (Cat No. NWKMDA01, NWLSS, USA), superoxide dismutase (SOD) (Cat. No. 706002, Cayman Chemical, Ann Arbor, MI, USA), and caspase 3 (Cat. No. R5814), Bcl-2 (Cat. No. R6813), and iNOS (Cat. No R6663) were purchased from STZ ELISA (USA) and used according to the manufacturers' instructions.

Statistical analysis. Statistical analyses were performed by using the Graphpad prism statistical software package (version 6). Data was presented as a means with their standard Deviation (mean $\pm \mathrm{SD}$ ). Normality and homogeneity of the data was confirmed before ANOVA. Differences among the experimental groups were assessed by one-way ANOVA followed by Tukey's t test. 


\section{RESULTS}

Induction of brain tissue damage by CUS. Chronic stress is well-known to induce brain injury related diseases such as memory loss and depression (Luo et al., 2016). CUS protocol is a recognised protocol for an animal model of depression (Harro et al.). To investigate whether a modified protocol for CUS which runs for three weeks can induce brain tissue damage in rats, harvested brain tissues from the animal groups were stained with $\mathrm{H} \& \mathrm{E}$ and examined under light microscopy. Compared to normal brain tissue architecture in the control group (Fig. 1A) that showed intact neurons $(\mathrm{N})$ with vesicular nucleus (n) and prominent nucleolus, glial processes (arrows) appear distinctly with preserved cell density. The small nuclei are from glial cells (G) which are more numerous. Whereas, tissue prepared from the cerebral cortex of the brain of the model group (CUS) of rats revealed profound tissue damage as demonstrated by a substantial severe neuronal $(\mathrm{N})$ damage with shrunken cells. In addition, disrupted atrophic nuclei (n), perineuronal vacuolation (arrows), and swollen glial cells (G) are seen (Fig. 1B).

Induction of tissue nitrosative and oxidative stress by CUS. Tissue oxidative stress is known to be involved in the pathology of neurodegenerative disease (Maes et al.). To determine whether the observed brain tissue damage induced by CUS in our rat model of the disease was also associated with the induction of biomarkers of nitrosative and oxidative stresses and inhibition of antioxidant biomarker in brain tissues, we measured iNOS, MDA as a by-product of lipid peroxidation and SOD using ELISA method in brain tissue homogenates of thecontrol and model groups of rats. As shown in Figures $2 \mathrm{~A}$ and $2 \mathrm{~B}$, CUS significantly $(\mathrm{p}<0.5)$ augmented iNOS and MDA levels, respectively, compared to the control group. Whereas, SOD tissue levels were significantly $(\mathrm{p}<0.5)$ inhibited by CUS (Fig. 2C).
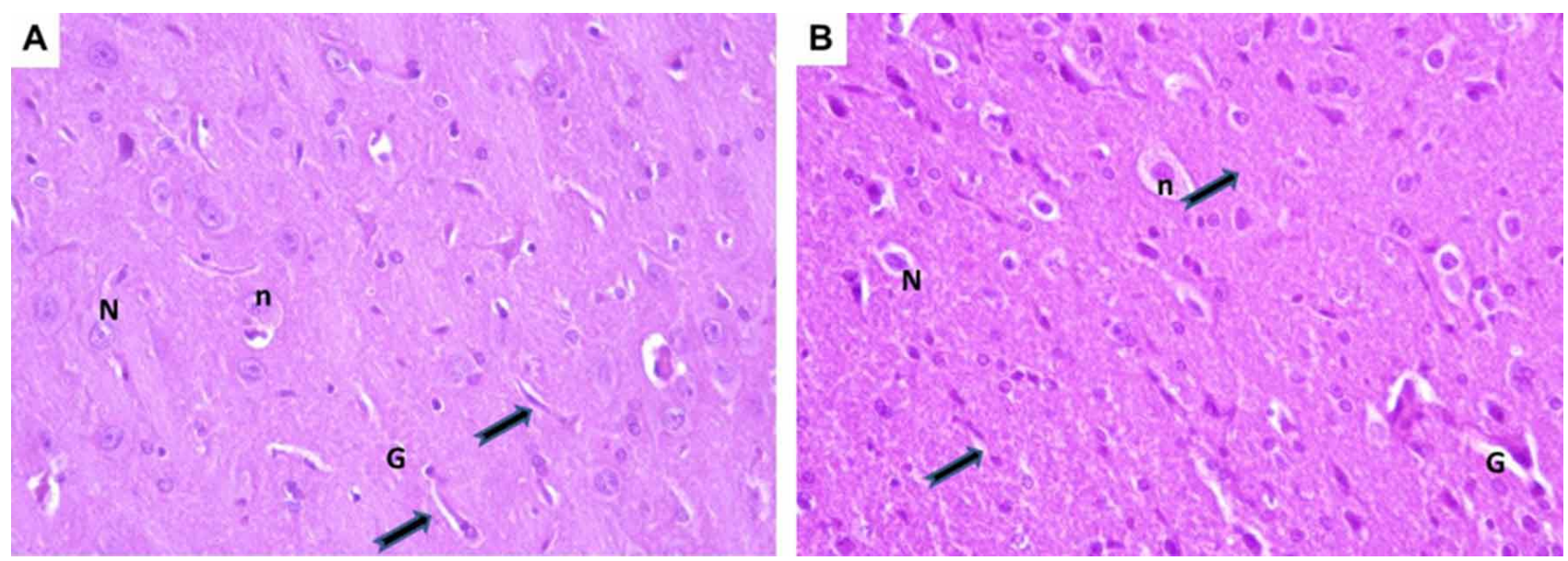

Fig. 1. CUS induces brain injury in rats. H\&E stained images (x400) of harvested tissues obtained from the cerebral cortex of the control group (A) compared with the model group (B) of rats are visualized using light microscopy. Note that in (A), arrows point to the glial processes, and in (B), point to the perineuronal vacuolation. Abbreviation: N, neurons; n, nucleus; G, glial cells.
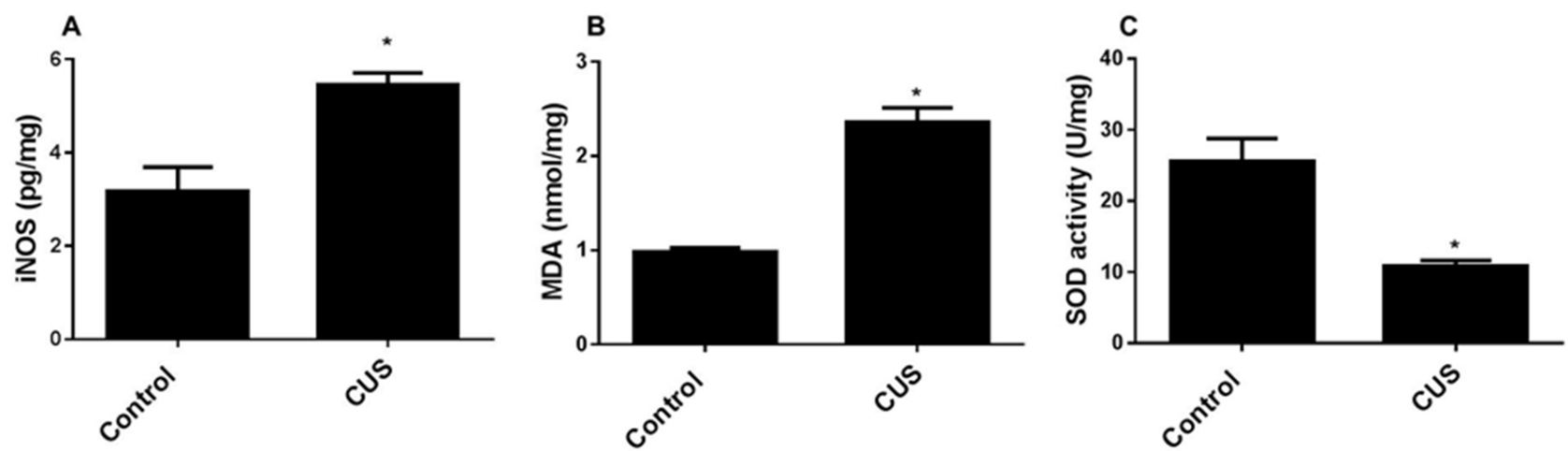

Fig. 2. CUS induces nitrosative and oxidative stress in rats. Brain tissue homogenates levels of iNOS (A), MDA (B), and SOD (C) were measured at the end of the experiment in the animal groups used in this study; Control group (Control) and the model group (CUS). Results represent the mean $( \pm \mathrm{SD}) ; \mathrm{n}=6$ for each group. Experiments were performed in triplicate. ${ }^{*} \mathrm{p}<0.05$ versus control. CUS: chronic uncontrolled stress; iNOS: inducible nitric oxide synthase; MDA: malondialdehyde; SOD: superoxide dismutase. 
Modulation of tissue apoptotic and antiapoptotic biomarkers by CUS. To determine whether the observed brain tissue damage and high levels of tissue oxidative and nitrosative stress induced by CUS in our rat model of the disease was also associated with the induction of apoptosis and inhibition of cell survival, we measured caspase- 3 and Bcl-2 protein levels. This was done using the ELISA method in brain tissue homogenates of the control and model groups of rats. As shown in Figures 3A and 3B, CUS significantly $(\mathrm{p}<0.5)$ augmented caspase-3 (Fig. 3A) and inhibited Bcl-2 (Fig. 3B) levels, compared to normal levels in the control group.

CUS inhibits mobility and climbing ability of rats. Oxidative damage to neurons has been implicated in the pathogenesis of depression (Hovatta et al.). To determine whether the observed brain tissue damage and high levels of tissue oxidative and nitrosative stress induced by CUS in our rat model of the disease can affect mobility and climbing ability, we assessed these parameters in rats using a depressive-like behavior forced swimming test. CUS significantly $(\mathrm{p}<0.5)$ increased immobility (decreased animal mobility) (Fig. 4A) and decreased climbing ability (Fig. 4B) compared to the control group of rats.
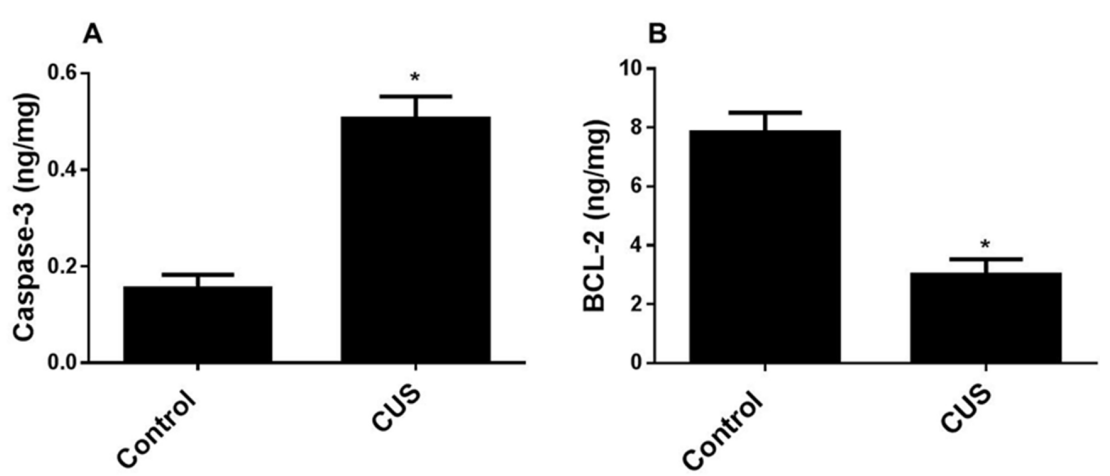

Fig. 3. CUS modulates biomarkers of apoptosis and anti-apoptosis in rats. Brain tissue homogenates levels of caspase-3 (A) and Bcl-2 (B) were measured at the end of the experiment in the animal groups used in this study; Control group (Control) and the model group (CUS). Results represent the mean ( $\pm \mathrm{SD})$; $\mathrm{n}=6$ for each group. Experiments were performed in triplicate. $* \mathrm{p}<0.05$ versus control. CUS: chronic uncontrolled stress; Bcl-2: B-cell lymphoma 2.
A

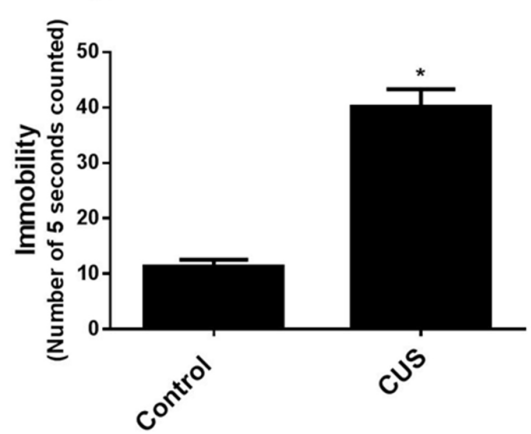

B

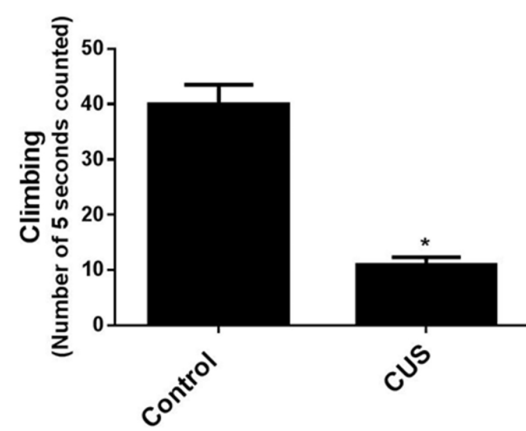

Fig. 4. CUS induces depressive-like behavior in rats. Immobility (A) and climbing ability (B) as a marker of depressive-like behavior forced swimming test was assessed at the end of the experiment in the animal groups used in this study; Control group (Control) and the model group (CUS). Results represent the mean $( \pm S D)$; $n=6$ for each group. Experiments were performed in triplicate. ${ }^{*} \mathrm{p}<0.05$ versus control. CUS: chronic uncontrolled stress.

\section{DISCUSSION}

The main objective of our study was to develop an animal model of brain injury, using a modified CUS protocol, which mimics the disease in humans caused by chronic stress. We also wished to compare the pathological effects induced by this model with the levels of brain injury biomarkers such as nitrosative stress, oxidative stress, apoptosis, and depression. Therefore, rats were exposed to a variety of unpredictable stressors daily before being sacrificed after 3 weeks compared with a 15-days CUS protocol originally reported (Harro et al.). The main findings of this study were that (a) CUS caused marked abnormalities in the histology and pathology of the brain in a rat model of the disease; (b) CUS significantly augmented biomarkers of nitrosative and oxidative stress, and apoptosis; (c) CUS significantly ameliorated biomarkers of antioxidant and cell survival; and (d) CUS significantly induced depression. These conclusions are supported by the data indicating that CUS markedly induced brain tissue injury (Fig. 1), nitrosative stress (iNOS) and oxidative stress (MDA) (Fig. 2), and apoptosis (caspase3). Furthermore, CUS caused a sharp decrease in SOD (Fig. 2), Bcl-2 (Fig. 3), mobility and climbing (Fig. 4). Our results were thus consistent with our working hypothesis that CUS can substantially induce brain tissue injury associated the modulation of biomarkers of brain injury in a rat model of the disease.

In cell signalling, nitrosative and oxidative stress are located upstream of the apoptotic and the survival biomarkers caspas-3 and Bcl-2 upon activation in many cases such as tissue injury (Iyaswamy et al., 2018; Liang \& $\mathrm{Su}, 2019)$. Our data that points to the induction of brain tissue injury, nitrosative and oxidative stress, and inhibition of SOD and Bcl-2 by CUS 
(Figs. 1-3) are in agreement with our recently published report (Al Humayed et al., 2020) that showed modulation of these parameters and induction of liver injury upon exposure to an insult in a similar way the CUS affected the brain. In addition, the findings of this study confirm those previously published and showed that both types of stress, acute and chronic, induced several pathological manifestations of brain injuries in animal models and humans (Zhao et al., 2019) such as behavior and oxidative status of restraint-stressed mice (Moretti et al., 2013), and psychological stress-induced enhancement of brain lipid peroxidation via nitric oxide (Matsumoto et al., 1999).

In summary, we have demonstrated that induction of CUS in rats for three weeks resulted in brain tissue damage and depression, possibly via augmentation of nitrosative and oxidative stress and apoptosis. This animal model can mimic the human disease and can be used to test potential protective drugs and agents.

\section{ACKNOWLEDGMENTS}

The author would like to express his gratitude to King Khalid University, Abha, Saudi Arabia for providing administrative and technical support. The support and input of Professors Bahjat Al-Ani and Mohamed Haidara from the Department of Physiology, and Professor Samir Zaki from the Department of Anatomy, College of Medicine, King Khalid University, Abha, Saudi Arabia, are highly appreciated. Also, the author would like to thank Dr. Mariam Al-Ani from Dental Care Partnership, Sutton Coldfield, Birmingham, UK for proofreading the manuscript.

BIN-JALIAH, I. Inducción de lesión cerebral y depresión en ratas por estrés crónico impredecible asociado con el aumento del estrés nitrosativo y la apoptosis. Int. J. Morphol., 38 (5):1217$1222,2020$.

RESUMEN: El estrés crónico es un factor de riesgo para el deterioro de la memoria y las anomalías neurológicas tanto en humanos como en animales. Intentamos investigar el alcance de (i) lesión del tejido cerebral; (ii) estrés nitrosativo y oxidativo en homogeneizados de tejido cerebral; (iii) biomarcadores apoptóticos y de supervivencia en homogeneizados de tejido cerebral; y (iv) inmovilidad y habilidades de escalada, inducidas durante un período de tres semanas por estrés crónico impredecible (ECI). Se dejaron sin tratamiento (grupo control) ratas Wistar, o se expusieron a una variedad de factores estresantes impredecibles diariamente antes de ser sacrificadas después de 3 semanas (grupo modelo). Se realizó una evaluación del comportamiento similar a la depresión y luego se sacrificaron los animales y se tiñeron los tejidos cerebrales con tinción histológica básica y se examinaron con microscopía óptica. Además, se prepararon homogeneizados de tejido cerebral y se analizaron los siguientes parámetros; óxido nítrico sintasa inducible (iNOS), malondialdehído (MDA), superóxido dismutasa (SOD), caspasa3 y linfoma de células B 2 (Bcl-2). Las imágenes histológicas mostraron que el CUS indujo un daño profundo en la corteza cerebral como lo demuestra el daño neuronal severo con células encogidas, núcleos atróficos alterados, vacuolación perineuronal y células gliales inflamadas. ECI también indujo significativamente $(\mathrm{p}<0,05)$ iNOS, MDA y caspase- 3 , mientras que los niveles de tejido cerebral SOD y Bcl-2 fueron inhibidos por ECI. Además, los datos del comportamiento similar a la depresión, la prueba de natación forzada mostró un aumento significativo $(\mathrm{p}<0,05)$ en la inmovilidad animal y una disminución en la capacidad de escalada en el grupo modelo de ratas. Por lo tanto, aquí demostramos un modelo confiable de daño cerebral crónico en rata inducido por el estrés, que se puede utilizar para investigar medicamentos o agentes beneficiosos usados durante un período de tres semanas para proteger el daño cerebral inducido por ECI.

PALABRAS CLAVE: Lesión cerebral; Estrés crónico; Apoptosis y supervivencia; Estrés nitrosativo y oxidativo; Modelo de rata.

\section{REFERENCES}

Al Humayed, S.; Al-Hashem, F., Haidara; M. A.; El Karib, A. O.; Kamar, S. S.; Amin, S. N. \& Al-Ani, B. Resveratrol pretreatment ameliorates p53-bax axis and augments the survival biomarker B-cell lymphoma 2 modulated by paracetamol overdose in a rat model of acute liver injury. Pharmacology, 105(1-2):39-46, 2020.

Alkadhi, K.; Zagaar, M.; Alhaider, I.; Salim, S. \& Aleisa, A. Neurobiological consequences of sleep deprivation. Curr. Neuropharmacol., 11(3):23149,2013

Bondi, C. O.; Rodriguez, G.; Gould, G. G.; Frazer, A. \& Morilak, D. A. Chronic unpredictable stress induces a cognitive deficit and anxietylike behavior in rats that is prevented by chronic antidepressant drug treatment. Neuropsychopharmacology, 33(2):320-31, 2008.

Carnevali, L.; Mastorci, F.; Audero, E.; Graiani, G.; Rossi, S.; Macchi, E.; Callegari, S.; Bartolomucci, A.; Nalivaiko, E.; Quaini, F.; et al. Stressinduced susceptibility to sudden cardiac death in mice with altered serotonin homeostasis. PLoS One, 7(7):e41184, 2012.

Chew, S. H. \& Toyokuni, S. Malignant mesothelioma as an oxidative stressinduced cancer: An update. Free Radic. Biol. Med., 86:166-78, 2015.

Dimsdale, J. E. Psychological stress and cardiovascular disease. J. Am. Coll. Cardiol., 51(13):1237-46, 2008.

Harro, J.; Häidkind, R.; Harro, M.; Modiri A. R.; Gillberg, P. G.; Pähkla, R.; Matto, V. \& Oreland, L. Chronic mild unpredictable stress after noradrenergic denervation: attenuation of behavioural and biochemical effects of DSP-4 treatment. Eur. Neuropsychopharmacol., 10(1):5-16, 1999.

Helmreich, D. L.; Parfitt, D. B.; Lu, X. Y.; Akil, H. \& Watson, S. J. Relation between the hypothalamic-pituitary-thyroid (HPT) axis and the hypothalamic-pituitary-adrenal (HPA) axis during repeated stress. Neuroendocrinology, 81(3):183-92, 2005.

Hovatta, I.; Juhila, J. \& Donner, J. Oxidative stress in anxiety and comorbid disorders. Neurosci. Res., 68(4):261-75, 2010. 
Iyaswamy, A.; Kammella, A. K.; Thavasimuthu, C.; Wankupar, W.; Dapkupar, W.; Shanmugam, S.; Rajan, R. \& Rathinasamy, S. Oxidative stress evoked damages leading to attenuated memory and inhibition of NMDAR-CaMKII-ERK/CREB signalling on consumption of aspartame in rat model. J. Food Drug. Anal., 26(2):903-16, 2018.

Liang, B. \& Su, J. Inducible nitric oxide synthase (iNOS) mediates vascular endothelial cell apoptosis in grass carp reovirus (GCRV)-induced hemorrhage. Int. J. Mol. Sci., 20(24):E6335, 2019.

Luo, Y.; Kuang, S.; Xue, L. \& Yang, J. The mechanism of 5-lipoxygenase in the impairment of learning and memory in rats subjected to chronic unpredictable mild stress. Physiol. Behav., 167:145-53, 2016.

Maes, M.; Galecki, P.; Chang, Y. S. \& Berk, M. A review on the oxidative and nitrosative stress (O\&NS) pathways in major depression and their possible contribution to the (neuro)degenerative processes in that illness. Prog. Neuropsychopharmacol. Biol. Psychiatry, 35(3):676-92. 2011.

Matsumoto, K.; Yobimoto, K.; Huong, N. T.; Abdel-Fattah, M.; Van Hien, T. \& Watanabe, H. Psychological stress-induced enhancement of brain lipid peroxidation via nitric oxide systems and its modulation by anxiolytic and anxiogenic drugs in mice. Brain Res., 839(1):74-84, 1999.

Moretti, M.; Budni, J.; Dos Santos, D. B.; Antunes, A.; Daufenbach, J. F.; Manosso, L. M.; Farina, M. \& Rodrigues, A. L. Protective effects of ascorbic acid on behavior and oxidative status of restraint-stressed mice. J. Mol. Neurosci., 49(1):68-79, 2013.

Ng, F.; Berk, M.; Dean, O. \& Bush, A. I. Oxidative stress in psychiatric disorders: evidence base and therapeutic implications. Int. J. Neuropsychopharmacol., 11(6):851-76, 2008.

Nunomura, A.; Tamaoki, T. \& Motohashi, N. Role of oxidative stress in the pathophysiology of neuropsychiatric disorders. Seishin Shinkeigaku Zasshi, 116(10):842-58, 2014.

O'Donnell, K.; Brydon, L.; Wright, C. E. \& Steptoe, A. Self-esteem levels and cardiovascular and inflammatory responses to acute stress. Brain Behav. Immun., 22(8):1241-7, 2008.

Pike, J. L.; Smith, T. L.; Hauger, R. L.; Nicassio, P. M.; Patterson, T. L.; McClintick, J.; Costlow, C. \& Irwin, M. R. Chronic life stress alters sympathetic, neuroendocrine, and immune responsivity to an acute psychological stressor in humans. Psychosom. Med., 59(4):447-57, 1997.

Won, M. H.; Kang, T. C.; Jeon, G. S.; Lee, J. C.; Kim, D. Y.; Choi, E. M.; Lee, K. H.; Choi, C. D.; Chung, M. H. \& Cho, S. S. Immunohistochemical detection of oxidative DNA damage induced by ischemia-reperfusion insults in gerbil hippocampus in vivo. Brain Res., 836(1-2):70-8, 1999.

Yankelevitch-Yahav, R.; Franko, M.; Huly, A. \& Doron, R. The forced swim test as a model of depressive-like behavior. J. Vis. Exp., (97):52587, 2015. DOI: https://www.doi.org/10.3791/52587

Zhao, X.; Cao, F.; Liu, Q.; Li, X.; Xu, G.; Liu, G.; Zhang, Y.; Yang, X.; Yi, $\mathrm{S}$; $\mathrm{Xu}, \mathrm{F}$; et al. Behavioral, inflammatory and neurochemical disturbances in LPS and UCMS-induced mouse models of depression. Behav. Brain Res., 364:494-502, 2019.
Corresponding author:

Professor Ismaeel Bin-Jaliah

Department of Physiology

College of Medicine

King Khalid University

P.O.Box 641

Abha, 61421, Aseer

SAUDI ARABIA

ORCID: Ismaeel Bin-Jaliah: 0000-0002-3029-2580

Email: isbinjaliah@kku.edu.sa

Received: 06-03-2020

Accepted: 04-05-2020 